\title{
Equidad como principio: una interpretación de su contenido
}

The principle of equity: an interpretation of its content

Equidade como princípio: uma interpretação de seu conteúdo

\author{
María de los Ángeles Jáuregui \\ Instituto Universitario Escuela Argentina \\ de Negocios, Argentina. \\ E-mail:maria.jauregui@ean.edu.ar
}

Fecha de recepción: 07/07/2017 Fecha de aceptación: 24/11/2017

\section{Resumen}

El presente artículo desarrolla la teoría de la justicia y los principios fundamentales de la misma que formuló John Rawls (1990). Esta se considera de ineludible conocimiento a fin de que sea la base de toda decisión social. Asimismo, se trata de relacionar dicha concepción con la equidad, definiendo esta última como la justicia en su aplicación al caso concreto de la obligación tributaria. Además, se hace mención de las distintas dimensiones de la equidad planteadas por Grazzo y Torres González (1992).

Luego, se hace hincapié en el concepto de García Belsunce (1989), quien considera que la equidad es un principio de imposición más que una garantía constitucional. Se la relaciona con otros principios tributarios

Palabras clave

- Principio de equidad

- Justicia

- Reforma tributaria

- Capacidad contributiva como ser: razonabilidad, igualdad, proporcionalidad, no confiscatoriedad, generalidad y capacidad contributiva.

Finalmente, se analizan la compatibilidad de los principios y su relación última con la justicia y los incentivos fiscales. 
Then, the concept proposed by García Belsunce (1989) is stressed: equity is a principle of imposition more than a constitutional guarantee.

Keywords

- Principle of equity

- Justice

- Tax reform

- Contributory capacity

Equity is related to other tax principles such as reasonableness, equality, proportionality, non-confiscation, generality and contributory capacity.

Finally, the extent to which principles are compatible and their ultimate relationship with justice and fiscal incentives are analyzed.

\section{Resumo}

Este trabalho desenvolve a teoria da justiça e dos princípios fundamentais de justiça feita por John Rawls (1990). Que é considerado conhecimento indispensável para que a justiça é a base de toda decisão social. Ele também tenta relacionar este conceito ao patrimônio definir isso como justiça na sua aplicação ao caso de responsabilidade fiscal. E a menção das diversas dimensões da equidade levantadas por Grazzo e Torres Gonzalez (1992) é feita.

Em seguida, a ênfase no conceito de García Belsunce (1989), que acredita que a equidade é um princípio da tributação, em vez de uma garantia constitucional, justiça, igualdade, proporcionalidade, não-confisco, gene-

Palavras-chave

- Princípio da equidade

- Justiça

- Reforma tributária

- Capacidade fiscal ralidade e capacidade de pagar: equidade fiscal com outros princípios, como se relaciona.

Finalmente, a harmonização dos princípios e sua última relação com a justiça e os incentivos fiscais analisadas. 